\title{
Correction \\ Correction: Pardo-Sánchez et al. Increased Tumor Growth Rate and Mesenchymal Properties of NSCLC-Patient-Derived Xenograft Models during Serial Transplantation. Cancers 2021, 13,2980
}

\author{
José Miguel Pardo-Sánchez ${ }^{1}\left(\mathbb{D}\right.$, Nuria Mancheño ${ }^{2,+}{ }^{+}$, José Cerón ${ }^{3, \dagger}$, Carlos Jordá ${ }^{3, \dagger}$, Emilio Ansotegui ${ }^{4}$, \\ Óscar Juan ${ }^{5}{ }^{(\mathbb{D}}$, Sarai Palanca ${ }^{6}\left(\mathbb{C}\right.$, Antonio Cremades ${ }^{7}$, Carolina Gandía ${ }^{1}$ and Rosa Farràs ${ }^{1, *(\mathbb{D})}$
}

check for

updates

Citation: Pardo-Sánchez, J.M.; Mancheño, N.; Cerón, J.; Jordá, C.; Ansotegui, E.; Juan, Ó.; Palanca, S.; Cremades, A.; Gandía, C.; Farràs, R. Correction: Pardo-Sánchez et al. Increased Tumor Growth Rate and Mesenchymal Properties of NSCLC-Patient-Derived Xenograft Models during Serial Transplantation. Cancers 2021, 13, 2980. Cancers 2021, 13, 4825. https://doi.org/10.3390/ cancers13194825

Received: 8 September 2021 Accepted: 14 September 2021 Published: 27 September 2021

Publisher's Note: MDPI stays neutral with regard to jurisdictional claims in published maps and institutional affiliations.

Copyright: (C) 2021 by the authors Licensee MDPI, Basel, Switzerland. This article is an open access article distributed under the terms and conditions of the Creative Commons Attribution (CC BY) license (https:/ / creativecommons.org/licenses/by/ $4.0 /)$.
1 Oncogenic Signalling Laboratory, Centro de Investigación Príncipe Felipe, 46012 Valencia, Spain; jmpardo@cipf.es (J.M.P.-S.); cgandia@cipf.es (C.G.)

2 Department of Pathology, University and Polytechnic La Fe Hospital, 46026 Valencia, Spain; manchenyo_nur@gva.es

3 Department of Thoracic Surgery, University and Polytechnic La Fe Hospital, 46026 Valencia, Spain; ceron_jos@gva.es (J.C.); jorda_car@gva.es (C.J.)

4 Department of Pulmonology, University and Polytechnic La Fe Hospital, 46026 Valencia, Spain; ansotegui_emi@gva.es

5 Department of Medical Oncology, University and Polytechnic La Fe Hospital, 46026 Valencia, Spain; juan_osc@gva.es

6 Molecular Biology Unit, Service of Clinical Analysis, University and Polytechnic La Fe Hospital, 46026 Valencia, Spain; palanca_sar@gva.es

7 Department of Pathology, Hospital Universitario de la Ribera, 46600 Alzira, Spain; cremades_antmir@gva.es

* Correspondence: rfarras@cipf.es

+ These authors equally contributed to this manuscript.

The authors would like to make a correction to their published paper [1]. There was a mistake in the original version of the article.

1. Figure S1A was uploaded instead of Figure 2A. Thus, Figure 2 should be replaced with the following version: 
A
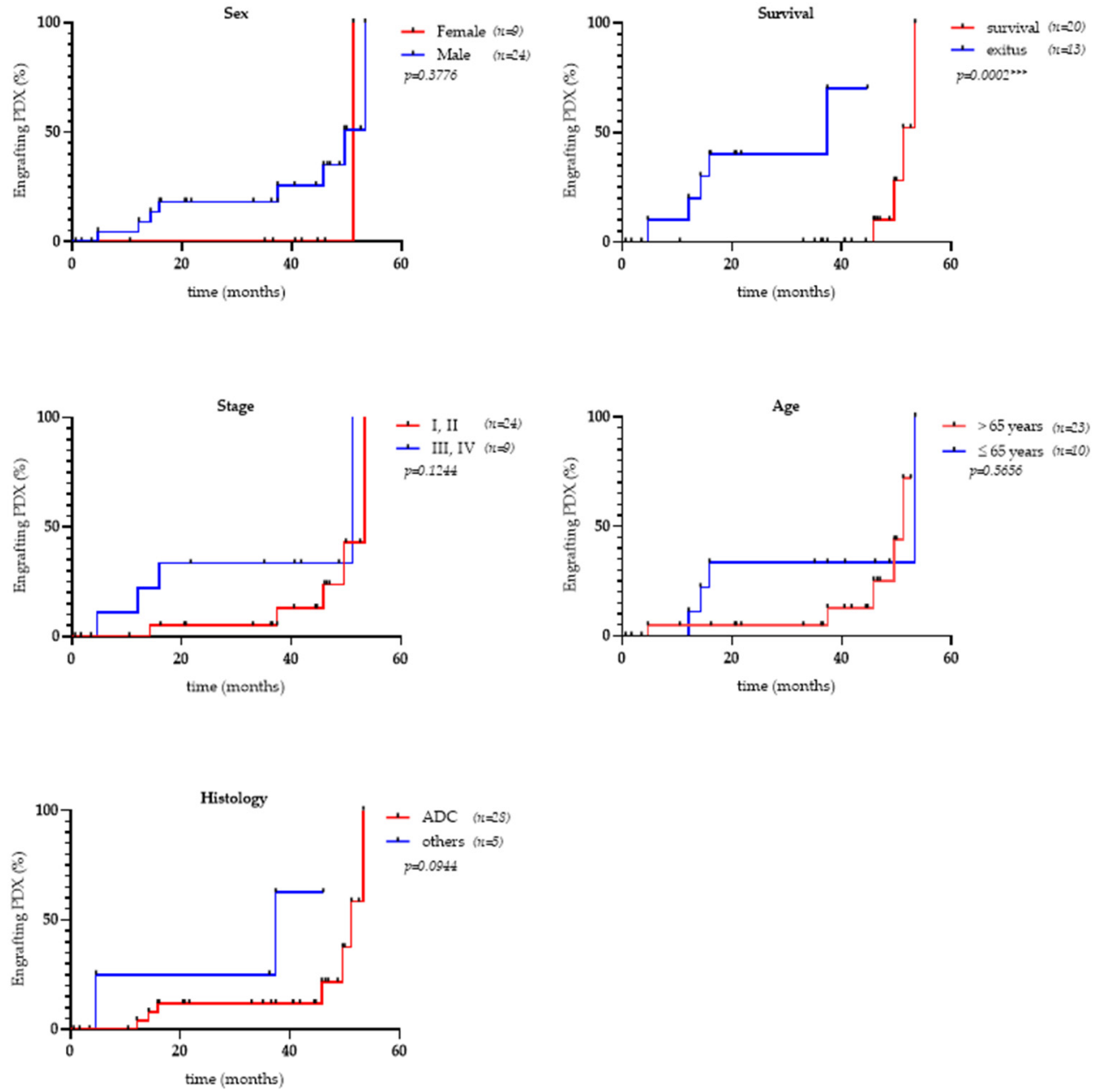

B

\begin{tabular}{cccc} 
& \multicolumn{3}{c}{ Engrafting and development of PDX } \\
\cline { 2 - 4 } & HazardRatio & CI (95\%) & p-value \\
\hline $\begin{array}{c}\text { Sex } \\
\text { (male vs. female) }\end{array}$ & 2.42 & $0.52-11.37$ & 0.3776 \\
\hline $\begin{array}{c}\text { Survival } \\
\text { (exitus vs. survival) }\end{array}$ & 7.11 & $1.14-44.44$ & 0.0002 \\
\hline $\begin{array}{c}\text { Stage } \\
\text { (I, II vs. III, IV) }\end{array}$ & 0.38 & $0.08-1.78$ & 0.1244 \\
\hline $\begin{array}{c}\text { Age } \\
\text { (>65 years vs. } \leq 65 \text { years) }\end{array}$ & 0.71 & $0.18-2.78$ & 0.5656 \\
\hline $\begin{array}{c}\text { Histology } \\
\text { (ADC vs. others) }\end{array}$ & 0.29 & $0.03-3.39$ & 0.0944 \\
\hline
\end{tabular}


2. In Table 3, the $\%$ allele frequencies of samples \#17 and $26 \#$ were missing. The original Table 3 should be replaced with the following Table 3:

Table 3. Somatic mutation in surgically resected tumors that generated PDXs.

\begin{tabular}{|c|c|c|c|}
\hline \multirow{2}{*}{$\begin{array}{c}\text { Sample Number } \\
\# 1\end{array}$} & \multirow{2}{*}{$\begin{array}{c}\begin{array}{c}\text { Patient } \\
\text { Code }\end{array} \\
\text { LF01 }\end{array}$} & \multicolumn{2}{|c|}{$\begin{array}{c}\text { Genetic Alterations } \\
\text { (Oncomine }{ }^{\mathrm{TM}} \text { Focus Assay) }\end{array}$} \\
\hline & & ERBB4 c.2139G >T; $p . \mathrm{L} 713 \mathrm{~F}$ & $9 \%$ allele frequency \\
\hline$\# 4$ & LF05 & KRAS c.34G>T; $p . G 12 C$ & $67 \%$ allele frequency \\
\hline$\# 8$ & LF09 & KRAS c.34G>T; $p . \mathrm{G} 12 \mathrm{C}$ & $7 \%$ allele frequency \\
\hline$\# 12$ & LF15 & $\begin{array}{c}\text { KRAS c.34G > T; } p . G 12 C \\
\text { ERBB2 c.2524G }>\text { A; } p . \text { V842I }\end{array}$ & $\begin{array}{l}32 \% \text { allele frequency } \\
4 \% \text { allele frequency }\end{array}$ \\
\hline$\# 17$ & LF20 & $\begin{array}{c}\text { ERBB2 c.2301C>G; } p . I 767 \mathrm{M} \\
\text { MYC c.77A }>\text { G; } p . N 26 S\end{array}$ & $\begin{array}{l}74 \% \text { allele frequency } \\
58 \% \text { allele frequency }\end{array}$ \\
\hline \#26 & LF29 & MET c.3029 C>T; p.T1010I & $29 \%$ allele frequency \\
\hline
\end{tabular}

3. In the Funding Section, acknowledgment to co-funding by ERDF/ESF, “Investing in your future" was missing. The Funding Section should be replaced with the following statement:

Funding: This research was funded by the Fondo de Investigación Sanitaria, ISCIII, grant numbers PI15-209 and PI20-194, co-funded by ERDF/ESF, "Investing in your future". J.M.P.-S. was funded by the Ministerio de Educación, Cultura, y Deporte, grant number FPU13/02755.

4. In addition, some minor typos have been corrected.

In the paragraph after Figure 2, "p.N11S" should be replaced with "p.N26S".

In the paragraph before the subheading of Section 2.5, "increased" should be replaced with "increase".

In the second paragraph of the Discussion Section, "SLCL" should be replaced with "SCLC".

In the penultimate paragraph of the Discussion Section, "NSLCL" should be replaced with "NSCLC".

The authors apologize for any inconvenience caused and state that the scientific conclusions are unaffected. The original article has been updated.

Conflicts of Interest: The authors declare no conflict of interest.

\section{Reference}

1. Pardo-Sánchez, J.M.; Mancheño, N.; Cerón, J.; Jordá, C.; Ansotegui, E.; Juan, Ó.; Palanca, S.; Cremades, A.; Gandía, C.; Farràs, R. Increased Tumor Growth Rate and Mesenchymal Properties of NSCLC-Patient-Derived Xenograft Models during Serial Transplantation. Cancers 2021, 13, 2980. [CrossRef] 